\title{
Responses of 'Golden Delicious' Apples to 1-MCP Applied in Air or Water
}

\author{
Luiz C. Argenta ${ }^{1}$, Xuetong Fan ${ }^{2}$, and James P. Mattheis ${ }^{3}$ \\ U.S. Department of Agriculture, ARS Tree Fruit Research Laboratory, \\ 1104 N. Western Avenue, Wenatchee, WA 98801
}

Additional index words. ethylene, fruit quality, color, superficial scald, physiological disorders

\begin{abstract}
The efficacy of the ethylene action inhibitor 1-methylcyclopropene (1-MCP) applied in water to slow ripening of 'Golden Delicious' [Malus sylvestris var. domestica (Borkh.) Mansf.] apples was evaluated in comparison with 1-MCP applied in air. The material was applied by dipping fruit in 1-MCP water solutions $\left(0.03,0.3\right.$, or $\left.3 \mathrm{mmol} \cdot \mathrm{m}^{-3}\right)$ for $4 \mathrm{~min}$ or by exposing fruit to 1 -MCP gas $\left(0.42,4.2\right.$, or $\left.42 \mu \mathrm{mol} \cdot \mathrm{m}^{-3}\right)$ in air for $12 \mathrm{~h}$. Fruit were held in air at $20^{\circ} \mathrm{C}$ for 25 days after treatment or stored at $0.5^{\circ} \mathrm{C}$ in air for up to 6 months followed by 7 days in air at $20^{\circ} \mathrm{C}$. Application of 1-MCP in water or air delayed the increase in respiration and ethylene production associated with fruit ripening and reduced the amount of fruit softening, loss of acidity, and change in peel color. Treatments applied in water required a 700 -fold higher amount of active ingredient compared with treatments applied in air to induce similar physiological responses. Fruit responses to 1-MCP varied with treatment concentration, and the maximum effects were obtained at concentrations of $4.2 \mathrm{or} 42 \mu \mathrm{mol} \cdot \mathrm{m}^{-3}$ in air and $3 \mathrm{mmol} \cdot \mathrm{m}^{-3}$ in water. Peel color change was impacted less than retention of firmness and titratable acidity for 1-MCP treatments applied at concentrations of 4.2 or $42 \mu \mathrm{mol} \cdot \mathrm{m}^{-3}$ in air and 0.3 or $3 \mathrm{mmol} \cdot \mathrm{m}^{-3}$ in water. Treatment with $1-\mathrm{MCP}$ in air or water was less effective for slowing peel degreening when treated fruit were stored at $0.5^{\circ} \mathrm{C}$ compared with storage at $20^{\circ} \mathrm{C}$. Fruit treated with 1-MCP and stored in air at $0.5^{\circ} \mathrm{C}$ developed a peel disorder typified by a gray-brown discoloration that is unlike other disorders previously reported for this cultivar. Symptoms were present when fruit were removed from cold storage and no change in symptom appearance was observed during a 7-d holding period at $20^{\circ} \mathrm{C}$.
\end{abstract}

The ethylene action inhibitor 1-methylcyclopropene (1-MCP) prevents plant tissues from responding to ethylene (Sisler and Blankenship, 1996) by combining with ethylene receptors (Sisler and Serek, 1997). Impacts of 1-MCP demonstrated for many apple cultivars include reduction of ethylene production and respiration rates, slower progression of ripening processes, including softening, loss of acidity, yellowing, volatile production, and reduced development of some physiological disorders (Fan et al., 1999a, 1999b; Ferenczi et al., 2006; Johnson, 2003; Lurie et al., 2002; Mattheis et al., 2005; Pre-Aymard et al., 2005; Rupasinghe et al., 2000; Watkins et al., 2000). Responses to 1-MCP for apples cold-stored in air can be comparable with that of midterm (4 to 6 months) CA storage of apples not treated with 1-MCP, and the combination of 1-MCP treatment followed by CA storage can ex-

Received for publication 18 Apr. 2007. Accepted for publication 24 June 2007.

Financial support for this research was received from the Washington State Tree Fruit Research Commission.

We thank David Buchanan and Janie Countryman for excellent technical assistance.

${ }^{1}$ Current address: EPAGRI, Estação Experimental, 89500-000, Caçador, SC, Brazil.

${ }^{2}$ Current address: USDA, ARS ERRC, 600 E. Mermaid Lane, Wyndmoor, PA 19038.

${ }^{3}$ To whom reprint requests should be addressed; e-mailmattheis@tfrl.ars.usda.gov. tend the effectiveness of 1-MCP treatment (DeLong et al., 2004; Mattheis et al., 2005; Watkins et al., 2000; Zanella, 2003).

Efficacy of 1-MCP for delaying apple fruit ripening is concentration and treatment duration-dependent (Argenta et al., 2005; Dauny and Joyce, 2002; DeEll et al., 2002; Fan et al., 1999a; Jayanty et al., 2004; PreAymard et al., 2003; Rupasinghe et al., 2000). Maximum benefits from 1-MCP treatment occur when apple fruit are harvested and treated at the preclimacteric stage of development (Argenta et al., 2005; Mir et al., 2001; Moran and McManus, 2005). Maximum control of fruit softening, superficial scald, and senescent breakdown for apples is achieved by treatment as soon after harvest as possible (Argenta et al., 2005; Watkins and Nock, 2005).

The low boiling point (less than $10{ }^{\circ} \mathrm{C}$ ) of 1-MCP (Sisler and Serek, 1997) allows the material to be applied as a gas in a sealed space, including commercial CA storage rooms. However, application of 1-MCP in water would enable postharvest treatments as a dip or line spray during the packing process. Application of 1-MCP in water could allow application when sealed rooms are not available, when room filling will be delayed, or to treat only fruit that will be packed after nonpackable fruit has been segregated. Field application of an aqueous 1-MCP solution applied to citrus reduces ethephon-induced leaf abscission with little effect on fruit detachment force (Pozo et al., 2004). The efficacy of a postharvest application of 1-MCP in water to delay ripening of a climacteric fruit has not been reported.

The objective of this study was to compare the efficacy of postharvest application of 1-MCP in air or water to alter ripening of 'Golden Delicious' apples during storage at $20{ }^{\circ} \mathrm{C}$ or after $\mathrm{CA}$.

\section{Materials and Methods}

'Golden Delicious' apples were harvested from the USDA, ARS Columbia View Experimental Plots near Wenatchee, WA. Application of 1-MCP gas $(0.42,4.2$, or 42 $\mu \mathrm{mol} \cdot \mathrm{m}^{-3}=0.01,0.1$, or $\left.1 \mu \mathrm{L} \cdot \mathrm{L}^{-1}\right)$ in air was performed at $20^{\circ} \mathrm{C}$ for $12 \mathrm{~h} 1 \mathrm{~d}$ after harvest. Generation of 1-MCP was performed at room temperature by mixing cyclodextrin-1-MCP powder (EthylBloc; BioTechnology for Horticulture, Burr Ridge, IL) and $10 \mathrm{~mL}$ of water in a $150-\mathrm{mL}$ flask sealed with a rubber stopper. After mixing, the flask and the 230-L treatment chamber were connected with Tygon tubing. The water solution in the flask was purged for $15 \mathrm{~min}$ by passing air from the treatment chamber while the headspace $1-\mathrm{MCP}$ gas from the flask was pumped into the treatment chamber in a closed loop. The concentration of 1-MCP in the treatment chamber was analyzed by gas chromatography using a 1-butene standard to generate a response factor of $42 \mu \mathrm{mol} \cdot \mathrm{m}^{-3}=5.2$ area counts (Fan et al., 1999b). Application of $1-\mathrm{MCP}$ in water at $20{ }^{\circ} \mathrm{C}$ (water and fruit temperature) was performed by dipping fruit for 4 min during the first $30 \mathrm{~min}$ after the solution was prepared in a ventilated open room. For each 1-MCP concentration made up in a final volume of $4 \mathrm{~L}$, five samples of 20 fruit were dipped sequentially. Concentrations of the 1-MCP solutions $(0.03,0.3$, or $3 \mathrm{mmol} \cdot \mathrm{m}^{-3}$ ) were based on the amounts of 1-MCP $\left(1.6,16\right.$, or $\left.162 \mu \mathrm{g} \cdot \mathrm{L}^{-1}\right)$ added to the water along with $0.05 \%$ Tween 20 . Addition of $0.05 \%$ Tween 20 was based on preliminary experiments that compared efficacy of 1-MCP solutions prepared in water alone or with various surfactants. The 1-MCP solutions were disturbed only when fruit were added and removed to minimize off-gassing of 1-MCP. Untreated controls were held for $12 \mathrm{~h}$ in air without 1-MCP in a similar steel chamber or dipped for $4 \mathrm{~min}$ in water containing $0.05 \%$ Tween 20 . After treatment, all fruit were held in air at $20{ }^{\circ} \mathrm{C}$ for $25 \mathrm{~d}$ or stored in air at $0.5^{\circ} \mathrm{C}$ for 3 or 6 months plus $7 \mathrm{~d}$ at $20{ }^{\circ} \mathrm{C}$.

Fruit quality was analyzed on the day after harvest, after $25 \mathrm{~d}$ at $20{ }^{\circ} \mathrm{C}$, or after 3 or 6 months of cold storage plus 1 or $7 \mathrm{~d}$ at $20{ }^{\circ} \mathrm{C}$. Fruit firmness, starch index $(1=100 \%$ starch coverage; $6=0 \%$ starch), titratable acidity (TA), soluble solids content, internal ethylene concentration (IEC), respiration, and ethylene production were analyzed as described earlier (Fan et al., 1999a; Mattheis et al., 1998). Peel color was measured with a colorimeter (Minolta CR-200, Osaka, Japan) using CIE illuminant $\mathrm{C}$ and an 8-mm-diameter 
aperture. Color values $\mathrm{a}^{*}$ and $\mathrm{b}^{*}$ were converted to hue angle $\left(\mathrm{h}^{\circ}\right)$ (McGuire, 1992). Peel color was also rated visually ( 1 = green, 5 = yellow) using a 'Golden Delicious' color chart (USDA, 1929). Superficial scald was visually assessed $(1=$ no scald; $7=$ dark scald and greater than $60 \%$ of the fruit surface affected) (Fan et al., 1999b). A peel disorder of unknown etiology manifested as a diffuse, grayish brown discoloration and observed during fruit evaluation was visually assessed as clear or affected. There was no difference in incidence of peel discoloration resulting from days of ripening after storage; therefore, data from day 1 and day 7 after removal from storage were pooled.

The experiment followed a completely random design with 20 single fruit replicates for each combination of treatment, storage temperature, and storage duration, except for determination of the peel discoloration disorder that followed a randomized complete block design with four replicates of 10 fruit. Data were analyzed by analysis of variance using SAS (SAS Institute, Raleigh, NC). Data for peel color and disorder ratings and percent incidence were transformed to SQRT $(x+0.5)$ before analysis of variance. Effects of 1-MCP concentration were analyzed using orthogonal contrasts. Significance of orthogonal polynomials was calculated by the F-test procedure. Treatment mean differences were identified using Fisher's protected least significant difference for time course rates of respiration and ethylene production.

\section{Results}

Fruit maturity at harvest. Fruit internal ethylene concentration at harvest was below $25 \mu \mathrm{mol} \cdot \mathrm{m}^{-3}$, and firmness and starch index averaged $65 \pm 5.4 \mathrm{~N}$ and $3.7 \pm 0.9$, respectively.

Fruit ripening at $20{ }^{\circ} \mathrm{C}$. Control fruit respiration increased during $25 \mathrm{~d}$ ripening at $20{ }^{\circ} \mathrm{C}$ (Fig. 1A). Maximum production of $\mathrm{CO}_{2}$ was detected between 9 and $15 \mathrm{~d}$ after harvest. Respiration by apples treated with 1-MCP in air was similar to or lower than the rate at harvest throughout the $25-\mathrm{d}$ period. Ethylene production by control fruit increased asymptotically, whereas ethylene production by 1-MCP fruit was reduced compared with control fruit (Fig. 1B). Ethylene production by fruit exposed to 4.2 and $42 \mu \mathrm{mol} \cdot \mathrm{m}^{-3}$ 1-MCP was not detectable for 21 or $18 \mathrm{~d}$ after treatment, respectively. Application of 1-MCP in water also resulted in altered respiration and ethylene production compared with control fruit (Fig. 1C-D). Ethylene production by fruit dipped in 0.3 or $3 \mathrm{mmol} \cdot \mathrm{m}^{-3} 1-\mathrm{MCP}$ in water was lower compared with control fruit through $25 \mathrm{~d}$ at $20{ }^{\circ} \mathrm{C}$ after treatment.

After $25 \mathrm{~d}$ at $20^{\circ} \mathrm{C}$, all fruit treated with $1-\mathrm{MCP}$ in air or fruit treated in water at 0.3 or $3 \mathrm{mmol} \cdot \mathrm{m}^{-3}$ were firmer, greener, and had higher TA compared with control fruit (Table 1). Concentration effects fit quadratic models indicating that fruit responses to $1-\mathrm{MCP}$ were maximized at concentrations lower than $42 \mu \mathrm{mol} \cdot \mathrm{m}^{-3}$ in air and lower than $3 \mathrm{mmol} \cdot \mathrm{m}^{-3}$ in water.

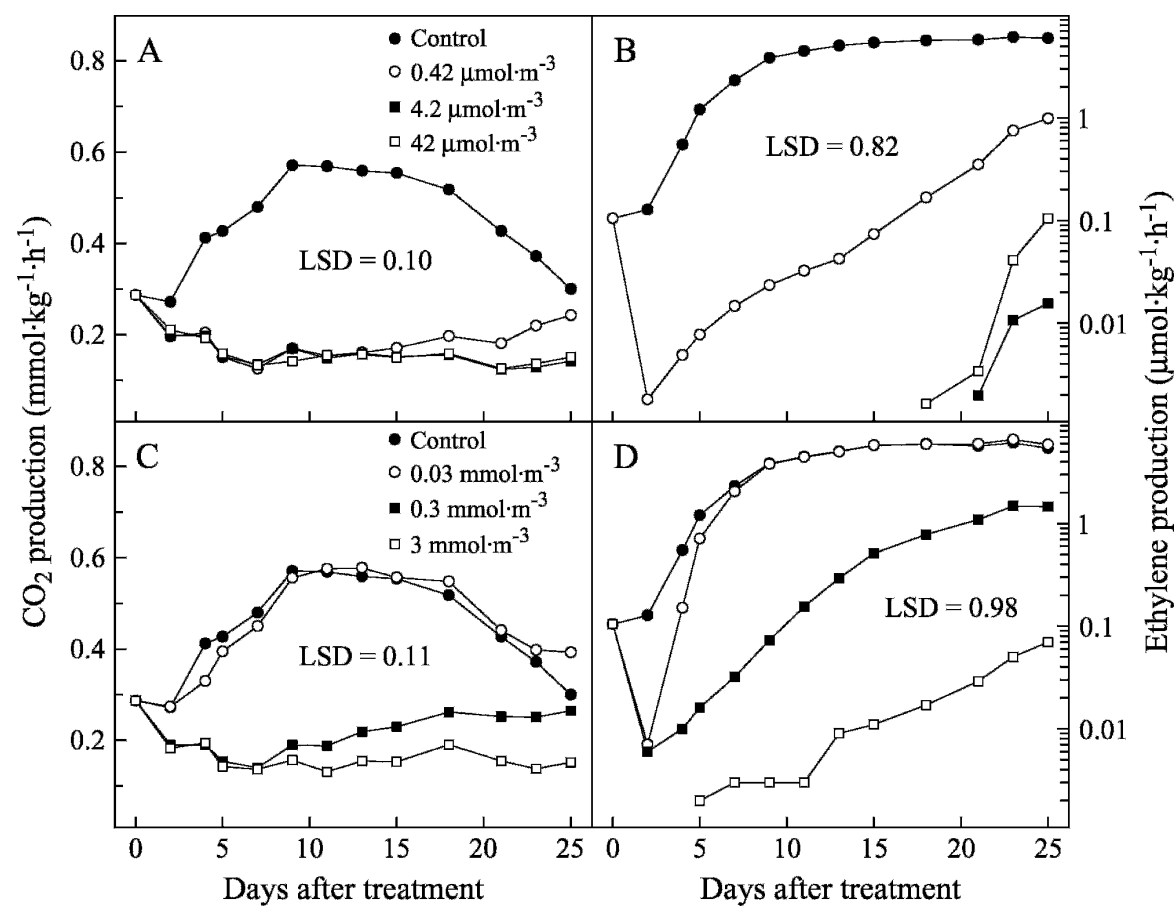

Fig. 1. Ethylene production and respiration rates of 'Golden Delicious' apples. Fruit were treated the day after harvest with $0.42,4.2$, and $42 \mu \mathrm{mol} \cdot \mathrm{m}^{-3} 1$-methylcyclopropene (1-MCP) in air for $12 \mathrm{~h}(\mathbf{A}, \mathbf{B})$ or by dipping in $0.03,0.3$, and $3 \mathrm{mmol} \cdot \mathrm{m}^{-3} 1-\mathrm{MCP}$ solutions for $4 \mathrm{~min}(\mathbf{C}, \mathbf{D})$. Fruit were held at $20^{\circ} \mathrm{C}$ for $25 \mathrm{~d}$ after treatment. Values are means of four replicate samples of $\approx 1 \mathrm{~kg}$ fruit. Legends in $\mathrm{A}$ and $\mathrm{C}$ also apply to $\mathrm{B}$ and $\mathrm{D}$, respectively. Inserted numbers indicate Fisher's least significant difference (LSD), $P<0.05$.
Quality of fruit stored at $0.5^{\circ} \mathrm{C}$. Impacts on ripening of fruit treated with 1-MCP in air or water and then stored at $0.5{ }^{\circ} \mathrm{C}$ were also concentration-dependent (Table 2). Treatments applied in air at 4.2 or $42 \mu \mathrm{mol} \cdot \mathrm{m}^{-3}$ 1 -MCP induced the most response for firmness, TA, color, and IEC. Application in water at $0.03 \mathrm{mmol} \cdot \mathrm{m}^{-3}$ had no detectable effects, and responses for firmness, TA, and color rated subjectively were greater for fruit treated at 3 compared with $0.3 \mathrm{mmol} \cdot \mathrm{m}^{-3} 1$ MCP. Visual ratings of peel color for control and 1-MCP-treated fruit $\left(0.42 \mu \mathrm{mol} \cdot \mathrm{m}^{-3}\right.$ after 3 months, 0.42 and $4.2 \mu \mathrm{mol} \cdot \mathrm{m}^{-3}$ after 6 months, $0.3 \mathrm{mmol} \cdot \mathrm{m}^{-3}$ after 3 months, 0.3 and $3 \mathrm{mmol} \cdot \mathrm{m}^{-3}$ after 6 months) were similar at evaluations when firmness and TA were higher in 1-MCP fruit. Objective (hue) and subjective color measurements did not always follow a similar pattern in relation to 1-MCP treatment concentrations.

There was a significant interaction $(P<$ $0.001)$ between storage temperature and 1MCP treatment concentration for fruit firmness, TA, and subjective peel color. In both control and 1-MCP-treated fruit, firmness and TA losses were higher $(P<0.05)$ after 6 months at $0.5^{\circ} \mathrm{C}$ plus $7 \mathrm{~d}$ at $20^{\circ} \mathrm{C}$ (Table 2) than after $25 \mathrm{~d}$ at $20^{\circ} \mathrm{C}$ (Table 1). Similarly, peel color was yellower $(P<0.001)$ for 1 MCP-treated fruit after 6 months at $0.5{ }^{\circ} \mathrm{C}$ compared with 1-MCP-treated fruit held $25 \mathrm{~d}$ at $20{ }^{\circ} \mathrm{C}$. However, control fruit peel was greener $(P<0.05)$ after 6 months at $0.5{ }^{\circ} \mathrm{C}$ than $25 \mathrm{~d}$ at $20^{\circ} \mathrm{C}$. Peel yellowing of control and 1-MCP-treated fruit stored at $20{ }^{\circ} \mathrm{C}$ was uniform over the whole fruit, but peel color change was not always uniform on 1-MCPtreated fruits stored 6 months at $0.5{ }^{\circ} \mathrm{C}$ (data not presented).

Superficial scald (scald) developed on control fruit after 6 months, but 1-MCP treatment reduced scald severity (Table 3 ). In contrast, 1-MCP-treated fruit exhibited an unusual peel disorder (Fig. 2) that had a diffuse, gray-brown discoloration after 3 and 6 months of storage that was not observed on control fruit (Table 4). Severity of peel discoloration increased with 1-MCP treatment concentration but did not increase from 3 to 6 months of storage or during $7 \mathrm{~d}$ at $20^{\circ} \mathrm{C}$ after removal from storage. None of the fruit harvested from three orchards in the next year developed this peel disorder regardless of 1-MCP treatment (data not presented).

\section{Discussion}

Responses of 'Golden Delicious' apples to $1-\mathrm{MCP}$ are influenced by $1-\mathrm{MCP}$ concentration, application in air or in water, storage temperature after treatment, and storage duration. Fruit exposed to $0.42 \mu \mathrm{mol} \cdot \mathrm{m}^{-3}$ 1-MCP in air began to produce ethylene sooner after treatment than fruit treated at 4.2 or $42 \mu \mathrm{mol} \cdot \mathrm{m}^{-3}$. Exposure of 'Golden Delicious' apples to 1-MCP in air at 4.2 or $42 \mu \mathrm{mol} \cdot \mathrm{m}^{-3}$ was similarly effective for maintenance of firmness, TA, and peel color, regardless of storage period, indicating that maximum benefit for fruit quality retention 
Table 1. Firmness (Firm), titratable acidity (TA), peel hue angle, and peel color index $(1=$ green; $5=$ yellow) of 'Golden Delicious' apples treated with $1-\mathrm{MCP}(\mathrm{n}=20)^{\mathrm{z}}$.

\begin{tabular}{|c|c|c|c|c|c|c|c|c|c|}
\hline \multicolumn{5}{|c|}{ 1-MCP in air } & \multicolumn{5}{|c|}{$1-\mathrm{MCP}$ in water } \\
\hline $\begin{array}{l}1-\mathrm{MCP} \\
\left(\mu \mathrm{mol} \cdot \mathrm{m}^{-3}\right)\end{array}$ & $\begin{array}{c}\text { Firm } \\
\mathrm{N}\end{array}$ & $\begin{array}{c}\text { TA } \\
(\%)\end{array}$ & $\begin{array}{l}\text { Hue } \\
\left(\mathrm{h}^{\circ}\right)\end{array}$ & $\begin{array}{l}\text { Color } \\
(1-5)\end{array}$ & $\begin{array}{c}1-\mathrm{MCP} \\
\left(\mathrm{mmol} \cdot \mathrm{m}^{-3}\right)\end{array}$ & $\begin{array}{c}\text { Firm } \\
\mathrm{N}\end{array}$ & $\begin{array}{l}\text { TA } \\
(\%)\end{array}$ & $\begin{array}{l}\text { Hue } \\
\left(\mathrm{h}^{\circ}\right)\end{array}$ & $\begin{array}{l}\text { Color } \\
(1-5)\end{array}$ \\
\hline 0 & 52.1 & 0.271 & 96.0 & 5.0 & 0 & 52.0 & 0.269 & 96.0 & 5.0 \\
\hline 42 & 65.4 & 0.380 & 108.2 & 1.6 & 3 & 66.3 & 0.351 & 105.5 & 2.1 \\
\hline & & Concentration & & & \multicolumn{5}{|c|}{ Concentration } \\
\hline $\mathrm{L}$ & $* *$ & $* *$ & $* *$ & * & $\mathrm{L}$ & $* * *$ & $* * *$ & $\mathrm{NS}^{\mathrm{y}}$ & * \\
\hline
\end{tabular}

Color ratings were transformed to SQRT $(\mathrm{x}+0.5)$ before analysis of variance.

${ }^{\mathrm{z}} \mathrm{Apples}$ were treated the day after harvest with $1-\mathrm{MCP}$ in air for $12 \mathrm{~h}$ or by dipping in 1 -MCP solutions for 4 min. Fruit were held at $20^{\circ} \mathrm{C}$ for $25 \mathrm{~d}$ after treatment. ${ }_{\mathrm{NSS}}, *, * * * * *$ Not significant or significant linear $(\mathrm{L})$ and quadratic $(\mathrm{Q})$ orthogonal polynomials at $P<0.05,0.01$, or 0.001 , respectively.

$\mathrm{N}=$ newtons; 1-MCP $=1$-methylcyclopropene.

Table 2. Firmness (Firm), titratable acidity (TA), peel hue angle, peel color index ( $1=$ green; $5=$ yellow), and internal ethylene concentration (IEC) of 'Golden Delicious' apples treated with 1-MCP $(\mathrm{n}=20)^{\mathrm{z}}$.

\begin{tabular}{|c|c|c|c|c|c|c|c|c|c|c|c|}
\hline \multicolumn{6}{|c|}{ 1-MCP in air } & \multicolumn{6}{|c|}{ 1-MCP in water } \\
\hline $\begin{array}{l}1-\mathrm{MCP} \\
\left(\mu \mathrm{mol} \cdot \mathrm{m}^{-3}\right)\end{array}$ & $\begin{array}{c}\text { Firm } \\
\mathrm{N}\end{array}$ & $\begin{array}{l}\text { TA } \\
(\%)\end{array}$ & $\begin{array}{l}\text { Hue } \\
\left(\mathrm{h}^{\circ}\right)\end{array}$ & $\begin{array}{l}\text { Color } \\
(1-5)\end{array}$ & $\begin{array}{c}\text { IEC } \\
\left(\mathrm{mmol} \cdot \mathrm{m}^{-3}\right)\end{array}$ & $\begin{array}{c}1-\mathrm{MCP} \\
\left(\mathrm{mmol} \cdot \mathrm{m}^{-3}\right)\end{array}$ & $\begin{array}{c}\text { Firm } \\
\mathrm{N}\end{array}$ & $\begin{array}{l}\text { TA } \\
(\%)\end{array}$ & $\begin{array}{l}\text { Hue } \\
\left(\mathrm{h}^{\circ}\right)\end{array}$ & $\begin{array}{l}\text { Color } \\
(1-5)\end{array}$ & $\begin{array}{c}\text { IEC } \\
\left(\mathrm{mmol} \cdot \mathrm{m}^{-3}\right)\end{array}$ \\
\hline \multicolumn{12}{|c|}{$3 \mathrm{mo}$} \\
\hline 4.2 & 58.9 & 0.412 & 105.6 & 2.2 & 0.2 & 0.3 & 51.5 & 0.351 & 102.7 & 3.2 & 2.1 \\
\hline 42 & 59.6 & 0.397 & 102.0 & 2.2 & 0.2 & 3 & 59.5 & 0.402 & 105.8 & 2.2 & 0.1 \\
\hline \multicolumn{6}{|c|}{ Concentration } & \multicolumn{6}{|c|}{ Concentration } \\
\hline \multicolumn{12}{|c|}{$6 \mathrm{mo}$} \\
\hline 0.42 & 51.8 & 0.253 & 96.3 & 4.8 & 9.1 & 0.03 & 45.0 & 0.194 & 100.2 & 3.5 & 17.6 \\
\hline 4.2 & 56.6 & 0.329 & 102.7 & 3.8 & 0.4 & 0.3 & 48.6 & 0.221 & 97.6 & 4.6 & 7.9 \\
\hline 42 & 55.7 & 0.309 & 101.3 & 3.2 & 0.3 & 3 & 55.2 & 0.293 & 99.7 & 3.3 & 0.2 \\
\hline \multicolumn{6}{|c|}{ Concentration } & \multicolumn{6}{|c|}{ Concentration } \\
\hline $\mathrm{L}$ & $* * *$ & $* * *$ & $* *$ & ** & $\mathrm{NS}^{\mathrm{y}}$ & $\mathrm{L}$ & $* * *$ & $* * *$ & NS & $*$ & $* * *$ \\
\hline
\end{tabular}

Color ratings were transformed to SQRT $(\mathrm{x}+0.5)$ before analysis of variance.

${ }^{2} \mathrm{Apples}$ were treated the day after harvest with 1-MCP in air for $12 \mathrm{~h}$ or by dipping in 1-MCP solutions for 4 min. Fruit were held at $0.5^{\circ} \mathrm{C}$ for 3 and 6 mo plus $7 \mathrm{~d}$ at $20{ }^{\circ} \mathrm{C}$.

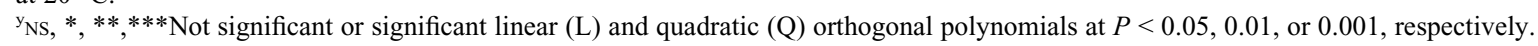

$\mathrm{N}=$ newtons; 1 -MCP $=1$-methylcyclopropene.

Table 3. Superficial scald severity of 'Golden Delicious' apples $(n=20)^{\mathrm{z}}$.

\begin{tabular}{|c|c|c|c|c|c|}
\hline \multicolumn{3}{|c|}{ 1-MCP in air } & \multicolumn{3}{|c|}{ 1-MCP in water } \\
\hline \multirow{2}{*}{$\begin{array}{l}1-\mathrm{MCP} \\
\left(\mu \mathrm{mol} \cdot \mathrm{m}^{-3}\right)\end{array}$} & \multicolumn{2}{|c|}{ Superficial scald (1-7) } & \multirow{2}{*}{$\begin{array}{c}1-\mathrm{MCP} \\
\left(\mathrm{mmol} \cdot \mathrm{m}^{-3}\right)\end{array}$} & \multicolumn{2}{|c|}{ Superficial scald (1-7) } \\
\hline & Day 1 & Day 7 & & Day 1 & Day 7 \\
\hline 0 & 2.1 & 3.4 & 0 & 2.3 & 3.0 \\
\hline 0.42 & 1.1 & 1.1 & 0.03 & 1.0 & 1.1 \\
\hline 4.2 & 1.0 & 1.0 & 0.3 & 1.0 & 1.1 \\
\hline \multirow[t]{2}{*}{42} & 1.0 & 1.0 & 3 & 1.1 & 1.1 \\
\hline & Concentration & & & entration & \\
\hline $\mathrm{L}$ & *y & * & $\mathrm{L}$ & $*$ & * \\
\hline Q & $* * *$ & $* * *$ & Q & $* * *$ & $* * *$ \\
\hline
\end{tabular}

Scald ratings were transformed to SQRT $(\mathrm{x}+0.5)$ before analysis of variance.

${ }^{\mathrm{z}}$ Apples were treated the day after harvest with 1-MCP in air for $12 \mathrm{~h}$ or by dipping in 1-MCP solutions for 4 min. Fruit were held at $0.5^{\circ} \mathrm{C}$ for 6 mo plus 1 and $7 \mathrm{~d}$ at $20^{\circ} \mathrm{C}$. Fruit were rated as $1=$ no scald to $7=$ dark scald over greater than $60 \%$ fruit surface.

y*,**,***Significant linear $(\mathrm{L})$ and quadratic $(\mathrm{Q})$ orthogonal polynomials at $P<0.05,0.01$, or 0.001 , respectively.

$\mathrm{N}=$ newtons; 1-MCP = 1-methylcyclopropene.

is likely to be obtained in this concentration range. These results are consistent with previous studies in which the saturation concentration of 1-MCP in apple fruit has been estimated at $\approx 42 \mu \mathrm{mol} \cdot \mathrm{m}^{-3}$ (Argenta et al., 2005; Dauny and Joyce, 2002; Fan et al., 1999a; Jayanty et al., 2004; Pre-Aymard et al., 2003; Rupasinghe et al., 2000; Watkins et al., 2000).

Similar to 1-MCP applied in air, application of 1-MCP in water delayed onset of the climacteric and fruit ripening during storage at $20{ }^{\circ} \mathrm{C}$ or $0.5{ }^{\circ} \mathrm{C}$. However, a 700 -fold higher amount of cyclodextrin-1-MCP pow- der was necessary to achieve similar fruit responses from 1-MCP applied in water compared with treatments applied in air. Although the amounts of cyclodextrin-1MCP added in the water treatments were high relative to treatments in air, some of the 1-MCP generated from cyclodextrin-1MCP was likely released from water into the treatment room as the solution was disturbed. 1-MCP efficacy was the same for fruit dipped 5 min or $2 \mathrm{~h}$ after preparation in water (data not shown) indicating the concentration of 1-MCP available in water established rapidly after preparation of the solution and may remain stable in undisturbed water for extended time periods. Reduced efficacy on a concentration basis for 1-MCP applied in water may occur as a result of a lower rate of diffusion of 1-MCP in water. Exposure of apples to 1-MCP in air for 1 to $4 \mathrm{~h}$ effectively prevented ripening (Argenta et al., 2005; DeEll et al., 2002; Pre-Aymard et al., 2003), indicating that $1-\mathrm{MCP}$ in air readily diffuses into fruit, possibly through lenticels as noted for $\mathrm{CO}_{2}$ and ethylene (Burg and Burg, 1965). The rate of entry of 1-MCP in water into fruit may be reduced by slower 


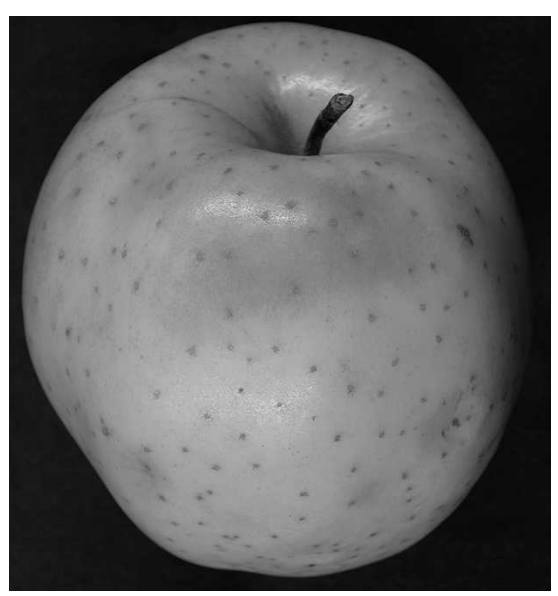

Fig. 2. 'Golden Delicious' apple exhibiting symptoms of peel disorder. Apple was treated the day after harvest with $42 \mu \mathrm{mol} \cdot \mathrm{m}^{-3} 1$-methylcyclopropene in air for $12 \mathrm{~h}$ and then held in air at $0.5^{\circ} \mathrm{C}$ for 3 months. Image was taken $1 \mathrm{~d}$ after removal from cold storage.

1-MCP diffusion and occlusion of lenticels by water.

Moderate yellowing of 'Golden Delicious' apple peel developing without excessive loss of firmness or TA can contribute positively to fruit marketability (Olsen et al., 1993). The lack of differences in peel color for control and some 1-MCP-treated fruit stored at low temperature results in fruit with a ripe (yellow) appearance that retains internal quality rivaling that at harvest. Similarly, 1-MCP-treated 'Cox' apples stored $180 \mathrm{~d}$ in CA were firmer but with a peel color similar to or yellower than that of untreated fruit (Johnson, 2003). 1-MCP treatment of 'Golden Delicious' is also more effective for slowing softening compared with yellow color development (Saftner et al., 2003).

The lack of consistent values for peel color determined objectively and subjectively reflects the nonuniformity of yellowing that can occur in 1-MCP treated 'Golden Delicious' apples stored at low temperature. The subjective rating is based on the rater's overall impression of peel color, whereas the objective rating is obtained from an 8-mm diameter peel section. The colorimeter readings were taken without any attempt to influence the value, i.e., positioning the measurement aperture based on visual assessment of green or yellow color. Because development of yellowing was often nonuniform over the peel surface of 1-MCPtreated fruit, the random measurement of peel color using the colorimeter may have contributed to values not indicative of the yellow character observed visually. This result is of interest because peel color is a critical factor determining 'Golden Delicious' apple commercial value (Olsen et al., 1993).

1-MCP treatment prevents development of superficial scald on 'Golden Delicious' apples (Table 3) as effectively as on other apple cultivars (Fan et al., 1999b; Rupasinghe et al., 2000; Watkins et al., 2000). In contrast, some 1-MCP-treated fruit developed a diffuse, grayish brown discoloration of the peel. The appearance of the affected peel tissues did not resemble other disorders (i.e., sunscald, delayed sunscald, $\mathrm{CO}_{2}$ injury) known to develop in the peel of this cultivar produced in the Pacific Northwest of North America (Pierson et al., 1971). Symptoms developed during the first 3 months of cold storage, but the disorder did not occur on fruit held at $20^{\circ} \mathrm{C}$ after 1-MCP treatment. Fruit harvested in year 2 from three different orchards stored 6 months at $0.5{ }^{\circ} \mathrm{C}$ did not develop this peel disorder indicating orchard or seasonal factors may predispose fruit to disorder development. Development of superficial scald on this cultivar is unusual and analysis of maturity at harvest did not indicate the fruit were immature. Whether superficial scald susceptibility is a factor predisposing 'Golden Delicious' apples to development of the diffuse discoloration disorder is unknown. In another 2-year study, 'Golden Delicious' apples treated at harvest with 1-MCP and then held at $38{ }^{\circ} \mathrm{C}$ for $4 \mathrm{~d}$ developed a superficial scald-like injury in one of 2 years (Saftner et al., 2003). This injury also developed during cold storage and, similar to our results, illustrates seasonal or orchard effects may contribute unpredictably to influence 'Golden Delicious' response to 1-MCP.

Table 4. Peel discoloration disorder incidence (\%) of 'Golden Delicious' apples after 3 and 6 mo of storage at $0.5^{\circ} \mathrm{C}^{\mathrm{z}}$

\begin{tabular}{|c|c|c|c|c|c|}
\hline \multicolumn{3}{|c|}{ 1-MCP in air } & \multicolumn{3}{|c|}{$1-\mathrm{MCP}$ in water } \\
\hline $\begin{array}{l}1-\mathrm{MCP} \\
\left(\mu \mathrm{mol} \cdot \mathrm{m}^{-3}\right)\end{array}$ & $3 \mathrm{mo}$ & $6 \mathrm{mo}$ & $\begin{array}{c}1-\mathrm{MCP} \\
\left(\mathrm{mmol} \cdot \mathrm{m}^{-3}\right)\end{array}$ & $3 \mathrm{mo}$ & $6 \mathrm{mo}$ \\
\hline 0 & 0 & 0 & 0 & 0 & 0 \\
\hline 0.42 & 31 & 17 & 0.03 & 0 & 0 \\
\hline 4.2 & 59 & 32 & 0.3 & 19 & 0 \\
\hline \multirow[t]{2}{*}{42} & 67 & 45 & 3 & 56 & 41 \\
\hline & Concentration & & & tration & \\
\hline $\mathrm{L}$ & $* * *$ & $* *$ & $\mathrm{~L}$ & $* * *$ & * \\
\hline Q & NS & $* * *$ & Q & $* * *$ & NS \\
\hline
\end{tabular}

Disorder incidence percentages were transformed to SQRT $(\mathrm{x}+0.5)$ before analysis of variance.

${ }^{\mathrm{z}}$ Apples were treated the day after harvest with 1-MCP in air for $12 \mathrm{~h}$ or by dipping in aqueous 1-MCP solutions for $4 \mathrm{~min}$. There were four replicates of 10 fruit for each treatment and storage duration.

Ns,*******Nonsignificant or significant linear (L) and quadratic (Q) orthogonal polynomials at $P<0.05$, 0.01 , or 0.001 , respectively.

1 -MCP $=1$-methylcyclopropene.
Application of 1-MCP in water delays the climacteric rise in respiration, ethylene production, softening, loss of acidity, peel color changes, and prevents development of superficial scald in 'Golden Delicious' apples as it does when applied as a gas in air. However, 1 -MCP applied in air is more efficient than 1-MCP applied in water based on the amount of a.i. necessary to induce similar physiological responses. Effects of 1-MCP in water or air are concentration- and storage temperature-dependent.

\section{Literature Cited}

Argenta, L.C., X. Fan, and J.P. Mattheis. 2005. Factors affecting efficacy of 1-MCP to maintain quality of apple fruit after storage. Acta Hort. 682:1249-1255.

Burg, S.P. and E.A. Burg. 1965. Gas exchange in fruits. Physiol. Plant. 18:870-884.

Dauny, P.T. and D.C. Joyce. 2002. 1-MCP improves storability of 'Queen Cox' and 'Bramley' apple fruit. HortScience 37:10821085.

DeEll, J.R., D.P. Murr, M.D. Porteous, and H.P.V. Rupasinghe. 2002. Influence of temperature and duration of 1-methylcyclopropene (1-MCP) treatment on apple quality. Postharvest Biol. Technol. 24:349-353.

DeLong, J.M., R.K. Prange, and P.A. Harrison. 2004. The influence of 1-methylcyclopropene on 'Cortland' and 'McIntosh' apple quality following long-term storage. HortScience 39:1062-1065.

Fan, X., S. Blankenship, and J.P. Mattheis. 1999a. 1-Methylcyclopropene inhibits apple ripening. J. Amer. Soc. Hort. Sci. 124:690-695.

Fan, X., S. Blankenship, and J.P. Mattheis. 1999b. Development of apple superficial scald, soft scald, core flush and greasiness is reduced by MCP. J. Agr. Food Chem. 47:30633068 .

Ferenczi, A., J. Song, M. Tian, K. Vlachonasios, D. Dilley, and R. Beaudry. 2006. Volatile ester suppression and recovery following 1-methylcyclopropene application to apple fruit. J. Amer. Soc. Hort. Sci. 131:691-701.

Jayanty, S.S., M. Canoles, and R.M. Beaudry. 2004. Concentration dependence of 'Redchief Delicious' apple fruit softening and chlorophyll fluorescence to repeated doses of 1-methylcyclopropene. J. Amer. Soc. Hort. Sci. 129:760765.

Johnson, D. 2003. Improvement in storage quality of apples in the UK by the use of 1-MCP $\left(\right.$ SmartFresh $\left.^{\text {TM }}\right)$. Acta Hort. 599:39-47.

Lurie, S., C. Pre-Aymard, U. Ravid, O. Larkov, and E. Fallik. 2002. Effect of 1-methylcyclopropene on volatile emission and aroma in cv. Anna apples. J. Agr. Food Chem. 50:4251-4256.

Mattheis, J.P., D.A. Buchanan, and J. Fellman. 1998. Volatile compounds emitted by 'Gala' apples following dynamic atmosphere storage. J. Amer. Soc. Hort. Sci. 123:426-432.

Mattheis, J.P., X. Fan, and L.C. Argenta. 2005. Interactive responses of 'Gala' apple fruit volatile production to controlled atmosphere storage and chemical inhibition of ethylene action. J. Agr. Food Chem. 53:4510-4516.

McGuire, R.G. 1992. Reporting of objective color measurements. HortScience 27:1254 1255.

Mir, N.A., E. Curell, N. Khan, M. Whitaker, and R.M. Beaudry. 2001. Harvest maturity, storage temperature, and 1-MCP application frequency alter firmness retention and chlorophyll 
fluorescence of 'Redchief Delicious' apples. J. Amer. Soc. Hort. Sci. 26:618-624.

Moran, R.E. and P. McManus. 2005. Firmness retention, and prevention of coreline browning and senescence in 'Macoun' apples with 1methylcyclopropene. HortScience 40:161-163.

Olsen, K.L., R.D. Bartram, and M. Williams. 1993. Golden Delicious apples: Productivity and quality with adequate but modest leaf nitrogen levels, p. 11-16. In R.D. Bartram (ed.). Apple maturity program handbook. USDA, Wenatchee, WA.

Pierson, C.F., M.J. Ceponis, and L.P. McColloch. 1971. Market diseases of apples, pears, and quinces. USDA, ARS. Bul. 376.

Pozo, L., R. Yuan, I. Kostenyuk, F. Alférez, G.Y. Zhong, and J.K. Burns. 2004. Differential effects of 1-methylcyclopropene on citrus leaf and mature fruit abscission. J. Amer. Soc. Hort. Sci. 129:473-478.

Pre-Aymard, C., E. Fallik, A. Weksler, and S. Lurie. 2005. Sensory analysis and instrumental measurements of 'Anna' apples treated with 1-methylcyclopropene. Postharvest Biol. Technol. 36:135-142.

Pre-Aymard, C., A. Weksler, and S. Lurie. 2003. Responses of 'Anna', a rapidly ripening summer apple, to 1-methylcyclopropene. Postharvest Biol. Technol. 27:163-170.

Rupasinghe, H.P.V., D.P. Murr, G. Paliyath, and L. Skog. 2000. Inhibitory effect of 1-MCP on ripening and superficial scald development in 'McIntosh' and 'Delicious' apples. J. Hort. Sci. Biotechnol. 3:271-276.

Saftner, R.A., J.A. Abbott, W.S. Conway, and C.L. Barden. 2003. Effects of 1-methylcyclopropene and heat treatments on ripening and postharvest decay in 'Golden Delicious' apples. J. Amer. Soc. Hort. Sci. 128:120-127.

Sisler, E.C. and S.M. Blankenship. 1996. Methods of counteracting an ethylene response in plants. US Patent No. 5,518,988.

Sisler, E.C. and M.E. Serek. 1997. Inhibitors of ethylene response in plants at the receptor level: Recent developments. Physiol. Plant. 100:577-582.
U.S. Department of Agriculture (USDA), Bureau of Plant Industry. 1929. Standard ground color chart for apples and pears in western states.

Watkins, C.B. and J.F. Nock. 2005. Effects of delays between harvest and 1-methylcyclopropene treatment, and temperature during treatment, on ripening of air-stored and controlled-atmosphere-stored apples. HortScience 40:2096-2101.

Watkins, C.B., J.F. Nock, and B.D. Whitaker. 2000. Responses of early, mid and late season apple cultivars to postharvest application of 1-methylcyclopropene (1-MCP) under air and controlled atmosphere storage conditions. Postharvest Biol. Technol. 19:1732.

Zanella, A. 2003. Control of apple superficial scald and ripening - a comparison between 1-methylcyclopropene and diphenylamine postharvest treatments, initial low oxygen stress and ultra low oxygen storage. Postharvest Biol. Technol. 27:69-78 